\title{
Total Selenium in Irrigation Drain Inflows to the Salton Sea, California, April 2009
}

Open-File Report 2009-1230 



\section{Total Selenium in Irrigation Drain Inflows to the Salton Sea, California, April 2009}

By Thomas W. May, Michael J. Walther, Michael K. Saiki, and William G.

Brumbaugh

Open-File Report 2009-1230 


\title{
U.S. Department of the Interior \\ KEN SALAZAR, Secretary
}

\author{
U.S. Geological Survey \\ Suzette M. Kimball, Acting Director
}

U.S. Geological Survey, Reston, Virginia: 2009

For more information on the USGS - the Federal source for science about the Earth, its natural and living resources, natural hazards, and the environment, visit http://www.usgs.gov or call 1-888-ASK-USGS

For an overview of USGS information products, including maps, imagery, and publications, visit http://www.usgs.gov/pubprod

To order this and other USGS information products, visit http://store.usgs.gov

Any use of trade, product, or firm names is for descriptive purposes only and does not imply endorsement by the U.S. Government.

Although this report is in the public domain, permission must be secured from the individual copyright owners to reproduce any copyrighted materials contained within this report.

Suggested citation:

May, T.W., Walther, M.J., Saiki, M.K., and Brumbaugh, W.G., 2009, Total selenium in irrigation drain inflows to the Salton Sea, California, April 2009: U.S. Geological Survey Open-File Report 2009-1230, 10 p. 


\section{Contents}

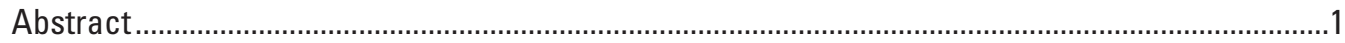

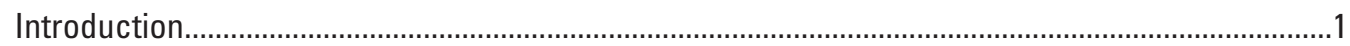

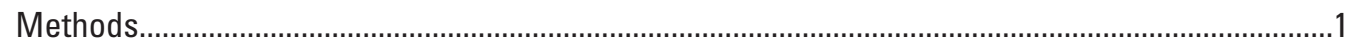

Field Collection and Preservation ...................................................................................

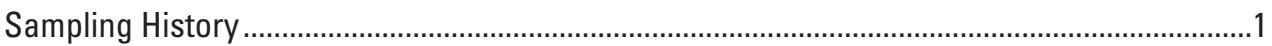

Homogenization and Lyophilization ................................................................................2

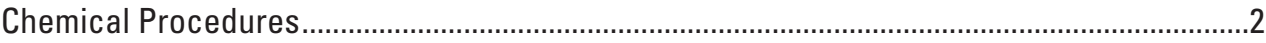

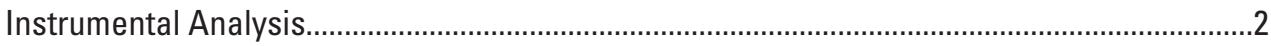

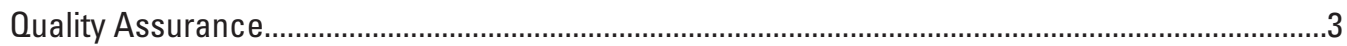

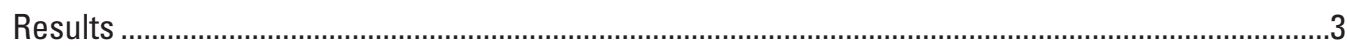

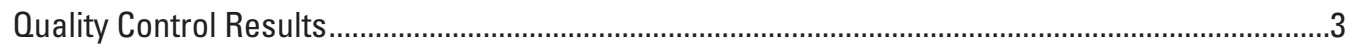

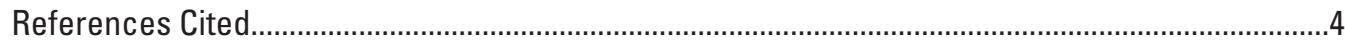

\section{Tables}

1. Total selenium concentrations in duplicates of unfiltered irrigation drain-water samples, Salton Sea, California, Ap ril 2009 ...................................................................6

2. Total suspended solids concentrations in unfiltered Salton Sea, California, irrigation drain-water samples, April 2009.......

3. Selenium concentrations in sediment samples collected from Salton Sea, California, irrigation drains, April 2009 ..............................................................................................8

4. Particle size distributions in sediment samples collected from Salton Sea, California, irrigation drains, April 2009..........................................................................................

5. Percent total organic carbon in sediment samples collected from Salton Sea, California, irrigation drains, April 2009.

\section{Conversion Factors, Abbreviations and Datums}

SI to Inch/Pound

\begin{tabular}{|c|c|c|}
\hline Multiply & By & To obtain \\
\hline \multicolumn{3}{|c|}{ Length } \\
\hline millimeter $(\mathrm{mm})$ & 0.03937 & inch (in.) \\
\hline \multicolumn{3}{|c|}{ Volume } \\
\hline liter $(\mathrm{L})$ & 33.82 & ounce, fluid (fl. oz) \\
\hline milliliter (mL) & .034 & ounce, fluid (fl. oz) \\
\hline \multicolumn{3}{|c|}{ Mass } \\
\hline $\operatorname{gram}(\mathrm{g})$ & 0.03527 & ounce, avoirdupois (oz) \\
\hline milligram (mg) & .000035 & ounce (oz) \\
\hline
\end{tabular}

Temperature in degrees Celsius $\left({ }^{\circ} \mathrm{C}\right)$ may be converted to degrees Fahrenheit ( $\left.{ }^{\circ} \mathrm{F}\right)$ as follows:

$$
{ }^{\circ} \mathrm{F}=\left(1.8 \times{ }^{\circ} \mathrm{C}\right)+32
$$

Concentrations of chemical constituents in water are given either in milligrams per liter (mg/L) or micrograms per liter $(\mu \mathrm{g} / \mathrm{L})$.

Concentrations of chemical constituents in solid materials are given in micrograms per gram $(\mu \mathrm{g} / \mathrm{g})$ dry weight 



\title{
Total Selenium in Irrigation Drain Inflows to the Salton Sea, California, April 2009
}

\author{
By Thomas W. May, Michael J. Walther, Michael K. Saiki, and William G. Brumbaugh
}

\section{Abstract}

This report presents the results for the final sampling period (April 2009) of a 4-year monitoring program to characterize selenium concentrations in selected irrigation drains flowing into the Salton Sea, California. Total selenium and total suspended solids were determined in water samples. Total selenium, percent total organic carbon, and particle size were determined in sediments. Mean total selenium concentrations in water ranged from 0.98 to 22.9 micrograms per liter. Total selenium concentrations in sediment ranged from 0.078 to 5.0 micrograms per gram dry weight.

\section{Introduction}

Monitoring surveys are being conducted by the U.S. Geological Survey (USGS) for 4 years to provide a profile of selenium concentrations in selected irrigation drain inflows to the Salton Sea, California. The 16th and final sampling in April, 2009, consisted of collecting water samples for total selenium and total suspended solids and collecting sediment for total selenium, percent total organic carbon, and particle size. This report presents these analytical results for this final collection period.

\section{Methods}

\section{Field Collection and Preservation}

The USGS sampling team used the laboratory at the U.S. Fish and Wildlife Service Sonny Bono Salton Sea National Wildlife Refuge (henceforth referred to as "the Refuge") for certain aspects of sample processing and for preparing samples for shipment during field trips to irrigation drains.

Unfiltered Water: Each water sample [1,000 milliliters $(\mathrm{mL})]$ to be analyzed for total selenium was poured through a 1-millimeter $(\mathrm{mm})$ polypropylene sieve attached to a 1-liter (L) precleaned borosilicate glass bottle. Upon collection, the water sample was acidified to less than $\mathrm{pH} 2$ with 6 normal
(N) hydrochloric acid $(\mathrm{HCl})$, chilled to approximately 4 degrees Celsius $\left(\sim 4^{\circ} \mathrm{C}\right)$, and kept in the dark during transport to the USGS. Each water sample $(1,000 \mathrm{~mL})$ intended for analysis of total suspended solids (TSS) was poured through a 1-mm polypropylene sieve attached to a precleaned widemouth 1-L polypropylene bottle. The TSS samples were chilled to approximately $\left(\sim 4{ }^{\circ} \mathrm{C}\right)$ during transport to the USGS.

Sediment: Five sampling points for sediment collection were identified along the length of each drain. At each sampling point, the uppermost 2 to 6 centimeters $(\mathrm{cm})$ of sediment were collected with a stainless steel dredge. The dredge was cleared of mud and rinsed with site water while used within a drain. At a new site, the dredge was rinsed with deionized (DI) water followed by site water before the first sample was collected. From each of the five sampling points, enough sediment to fill a $250-\mathrm{mL}$ container was collected and mixed to form a composite sample $(1,250-\mathrm{mL}$ total). An aliquot of this composite was then placed into a 120 - and a $500-\mathrm{mL}$ polypropylene container for each drain sampled. All containers were placed on ice in the field. Samples were chilled $\left(\sim 4^{\circ} \mathrm{C}\right)$ during transport to the USGS.

\section{Sampling History}

The irrigation drain monitoring samples collected by USGS personnel were received in two shipments by the Environmental Chemistry Branch Inorganic Section (henceforth referred to as "the laboratory") of the USGS shortly after collection to meet the 7-day holding time specified for TSS in water and the 14-day holding time for total organic carbon (TOC) in sediments.

The first set of samples was collected April 17 and 18, 2009, was received by the laboratory on April 21, 2009, and contained 15 TSS water samples, 24 water samples for total selenium, and 4 sediment samples for total selenium. The samples were assigned USGS batch number 1582 and USGS sample identification numbers 46140 to 46182 .

The second set of samples was collected from April 19 to 21, 2009, was received by the laboratory on April 23, 2009, and contained 6 TSS water samples, 12 water samples and 12 sediment samples for total selenium, and 14 sediment samples for TOC and particle size analysis (PSA). The samples were 
assigned USGS batch number 1584 and USGS sample identification numbers 46208 to 46251 .

The third set of samples was collected April 21 and 24, 2009, was received by the laboratory on April 28, 2009, and contained 10 TSS water samples, 26 water samples and 15 sediment samples for total selenium, and 17 sediment samples for TOC and PSA. The samples were assigned USGS batch number 1585 and USGS sample identification numbers 46252 to 46319 .

\section{Homogenization and Lyophilization}

Sediment samples designated for total selenium analysis were lyophilized in a Virtis Genesis ${ }^{\circledR}$ 35EL freeze dryer. Percent moisture was determined as part of the lyophilization process. After lyophilization, dried sediment was placed into a plastic bag, sealed, and then pulverized by using a rolling pin on the plastic bag to produce a coarse powder product.

\section{Chemical Procedures}

Total Selenium in Water: Before analysis, all water samples were stored in the dark at $\sim 4^{\circ} \mathrm{C}$. For the subsequent determination of total selenium in filtered and unfiltered samples, a $20-\mathrm{mL}$ aliquot of each acidified water sample was subjected to an $\mathrm{HNO}_{3}$-magnesium nitrate $\left[\mathrm{Mg}\left(\mathrm{NO}_{3}\right)_{2}\right]$ ashing procedure, followed by treatment with $\mathrm{HCl}$. The ashing procedure consisted of three steps: (1) boiling with $\mathrm{HNO}_{3}$ for solubilization and partial oxidation; (2) ashing at $500{ }^{\circ} \mathrm{C}$ with $\mathrm{Mg}\left(\mathrm{NO}_{3}\right)_{2}$ to complete the oxidation and decompose remaining organic matter; (3) and heating with $20 \mathrm{~mL}$ of 50 percent $(\mathrm{v} / \mathrm{v}) \mathrm{HCl}$ to dissolve the ash and chemically reduce selenium to the selenite $\left(\mathrm{Se}^{+4}\right)$ oxidation state required for detection by hydride generation atomic absorption spectrophotometry. Following reduction, digestates were diluted to $\sim 100 \mathrm{~mL}$ with DI water, yielding a final acid matrix of 10 percent $\mathrm{HCl}$.

Sediment: An approximately 0.25 -gram (g) aliquant of each dried sample was subjected to a $\mathrm{HNO}_{3}-\mathrm{Mg}\left(\mathrm{NO}_{3}\right)_{2}$ ashing procedure, followed by $\mathrm{HCl}$ chemical reduction of selenate to selenite for the determination of selenium. The steps in the procedure were the same as those described above for total selenium in water. Digestates were diluted to about $100 \mathrm{~mL}$ with DI water, yielding a final acid matrix of 10 percent $\mathrm{HCl}$.

\section{Instrumental Analysis}

Total Selenium: Total selenium was determined in all ashed samples by flow injection hydride generation atomic absorption spectrophotometry (FIHGAAS). For this procedure, the digestate is mixed with an $\mathrm{HCl}$-carrier solution and then reduced by sodium tetrahydridoborate that has been stabilized with sodium hydroxide. Selenium in the sample is converted to volatile hydrogen selenide and transferred with argon carrier gas into a heated quartz cell mounted on an atomic absorption spectrophotometer for decomposition into atomic vapor and measurement.

Total Suspended Solids: Upon arrival at the laboratory, all TSS samples were transferred to the Ecology Branch for TSS analysis. TSS were analyzed with methods recommended by the American Public Health Association (1998). Samples were brought to room temperature and mixed with a magnetic stirrer and subsequent manual inversions of the sample container. The sample was measured into a graduated cylinder, poured into a filtration apparatus, and filtered through a ProWeigh ${ }^{\circledR}$ glass fiber filter. The samples were prewashed three times in DI water, dried at $105^{\circ} \mathrm{C}$, and weighed to the nearest 0.1 milligram $(\mathrm{mg})$. Sample volume varied to yield a dried residue between 2.5 and $200 \mathrm{mg}$. For each volume of sample used, an equal volume of DI water also was filtered for a blank determination. After filtering, large or nonhomogeneous materials were removed from the filter and the filter was rinsed with three $10-\mathrm{mL}$ aliquots of DI water. Filters were then dried for at least 1 hour in an oven at 103 to $105^{\circ} \mathrm{C}$. After cooling to room temperature in a desiccator, filter and residue were weighed to the nearest $0.1 \mathrm{mg}$. Drying, cooling, and weighing of the filter were repeated until the weight difference was less than $(<) 4$ percent or $0.5 \mathrm{mg}$, whichever was less. The average of these weights was used to determine the constant weight of the filter and residue, which was then corrected for any weight gain or loss of the blank. After subtracting the filter weight, this blank-corrected dried residue in milligrams was divided by the sample volume in liters to yield TSS in milligrams per liter $(\mathrm{mg} / \mathrm{L})$.

Particle-Size Analysis: Sediment samples designated for PSA were transferred to the USGS Ecology Branch upon arrival. The method requires use of a Bouyoucos hydrometer, adapted from American Society for Testing and Materials (2003). Wet sediment was sieved through a 2-mm sieve to remove any particles larger than coarse sand and then dried at $60{ }^{\circ} \mathrm{C}$ using a convectional drying oven. Approximately $100 \mathrm{~g}$ of dried sediment was mixed with $250 \mathrm{~mL}$ of DI water and $100 \mathrm{~mL}$ of a $50 \mathrm{mg} / \mathrm{L}$ sodium hexametaphosphate solution. A stir bar was then added and the mixture was stirred with a magnetic stirring plate. After calibrating the hydrometer, the suspended sediment mixture was transferred to a sedimentation cylinder and the volume adjusted to $1 \mathrm{~L}$ with DI water. After allowing for thermal equilibration, the temperature was recorded. Cylinder contents were then mixed thoroughly, and the hydrometer was inserted into the suspension. The meniscus reading was taken after 30 seconds and the hydrometer was removed and dried. After 120 minutes, the hydrometer was reinserted and the meniscus read again. All hydrometer meniscus readings were corrected by adjusting +0.25 for each degree above $18{ }^{\circ} \mathrm{C}$ and -0.25 for each degree below $18{ }^{\circ} \mathrm{C}$. Percent fractions were determined as follows:

- Grams sand $=$ sediment dry weight $-($ corrected 30 second reading - corrected calibration);

- Percent sand = grams sand/sediment dry weight x 100; 
- Grams clay $=$ sediment dry weight $-($ corrected 120 minute reading - corrected calibration);

- Percent clay $=$ grams clay/sediment dry weight $\mathrm{x} 100$; and

- Percent silt $=100-$ (percent sand + percent clay $)$.

Total Organic Carbon: TOC was determined with a Universal Instruments Corporation (UIC) Model 5014 Coulometer that determines carbon in any carbon dioxide $(\mathrm{CO} 2)$ containing gas stream (Universal Instruments Corporation, 1999). The coulometer was used as a detector with different carbon frontend units and detected carbon in the range of 0.01 micrograms $(\mu \mathrm{g})$ to $100 \mathrm{mg}$. The coulometer cell was filled with a proprietary solution containing monoethanolamine and a colorimetric $\mathrm{pH}$ indicator. Platinum (cathode) and silver (anode) electrodes were positioned in the cell. The cell assembly was then placed in the coulometer cell compartment between a light source and

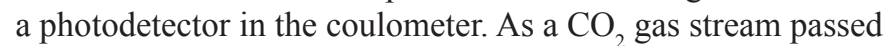
into the cell, the $\mathrm{CO}_{2}$ was quantitatively absorbed and reacted with the monoethanolamine to form a titratable acid. This acid caused the color indicator to fade. A photodetector monitored the change in the color of the solution as a percent transmittance (percent $\mathrm{T}$ ). As the percent $\mathrm{T}$ increased, the titration current automatically was activated to electrochemically generate base at a rate proportional to the percent $\mathrm{T}$ (approximately $1,500 \mu \mathrm{g}$ carbon/minute). When the solution returned to its original color (original percent $\mathrm{T}$ ), the current stopped.

For TOC analysis, total carbon (TC, $\mu \mathrm{g} / \mathrm{mg}$ ) and total inorganic carbon (TIC, $\mu \mathrm{g} / \mathrm{mg}$ ) were determined. Total carbon was determined by combustion of weighed sediments at $925^{\circ} \mathrm{C}$. In TIC analysis, weighed sediments were exposed to heated $2 \mathrm{~N}$ sulfuric acid. Any inorganic carbonates were chemically reduced to mineral components and $\mathrm{CO} 2$ gas. The gas was carried in high purity oxygen to the coulometer cell, where it was measured by the procedure described above. Percent TOC was calculated as follows:

$$
\text { Percent TOC }=[(\mathrm{TC}-\mathrm{TIC}) / \mathrm{TC}] \times 100
$$

\section{Quality Assurance}

Samples were processed through the preparative and analytical flow scheme in three analytical blocks for selenium and one block each for TSS, PSA, and TOC. Each block was assigned a block initiation date (BID) used to identify samples and quality-control samples/materials prepared and analyzed collectively as a unit. For samples analyzed by atomic absorption for total selenium, predigestion quality control included digestion blanks, replicates, spikes, and reference solutions. Analytical quality-control for selenium included calibration verification solutions, replicate analyses, and analysis spikes. Quality control for the TSS, PSA, and TOC determinations included reference materials, duplicates, and replicates.

\section{Results}

Total Selenium: Total selenium concentrations [micrograms per liter, $(\mu \mathrm{g} / \mathrm{L})]$ in unfiltered water samples for the April 2009 samples are listed in table 1 (at the back of this report). Mean selenium concentrations were most elevated in water from Trifolium 18 drain (22.9), followed by Q drain (9.73). The lowest mean selenium concentration was from Trifolium 14 drain (0.98).

Total Suspended Solids: TSS concentrations ( $\mathrm{mg} / \mathrm{L})$ in unfiltered water collected during the April 2009 samplings are presented in table 2 (at the back of this report). TSS concentrations ranged from a high of 856 (W drain) to a low of 4.7 (Trifolium 18 drain).

Sediment: Percent moisture and selenium concentrations ( $\mu \mathrm{g} / \mathrm{g}$ dry weight) in sediment are presented in table 3 (at the back of this report). Percent moistures ranged from 22.1 to 71.6. Selenium concentrations in sediment ranged from 0.08 (Former Trifolium 20) to 5.99 (Vail 5). The particle size analyses of sediments, expressed as percent sand, silt, and clay, are presented in table 4 (at the back of this report). Percent sand ranged from 0 to 88 ; percent silt from 7.5 to 59 ; and percent clay from 4.7 to 74 . Percent TOC in sediments is given in table 5 (at the back of this report) and ranged from 0.2 (Trifolium 12 and Trifolium Storm) to 3.7 (Lack and Linsey Pond).

\section{Quality-Control Results}

Calibration Verification: During the selenium determinations, a calibration verification solution (Spex Claritas PPT $^{\circledR}$;

Cat No. CLSe2-2Y) was analyzed at the beginning and end of each analytical run. Calibration was considered acceptable if the check solution was within plus or minus 10 percent of the actual concentration $(3 \mu \mathrm{g} / \mathrm{L})$, which was achieved during all analyses.

Reference Materials: Recoveries of selenium from QC Plus+ Trace Metals Quality Control Standard [n=2 (2 samples)] and National Institute of Standards and Technology (NIST) Standard Reference Material (SRM) 1643e Trace Elements in Water $(n=2)$ averaged 106 percent. The recoveries of selenium from National Research Council of Canada (NRCC) PACS-1 and MESS-3 $(n=2)$ and NIST $2702(n=1)$ marine sediments were 100 percent. Recoveries of TSS from a TSS reference solution (Environmental Resource Associates Hardness Wastewater Standard 507; n=3) were 100 percent. The recovery of total carbon from a carbon reference material (Environmental Resource Associates Nutrients in Soil 542; $\mathrm{n}=1$ ) was 100 percent. Recoveries of percent sand, silt, and clay from a USGS research sediment material ranged from 93 to 106 percent.

Analytical and Method Precision: Instrumental precision for selenium as determined by repeated analysis of a standard throughout the run for each block $(n=3)$ was less than 4 percent relative standard deviation (RSD). Relative percent 
differences (RPDs) between field duplicates $(n=29)$ of unfiltered water samples analyzed for selenium mostly were $\leq$ (less than or equal to) $8(\mathrm{n}=27)$, but two of these duplicates exhibited greater RPDs of 12 and 17 . Laboratory method precision for the triplicate preparation and analysis of water $(\mathrm{n}=4)$ and sediment $(\mathrm{n}=2)$ samples for selenium was $<5$ percent $\mathrm{RSD}$. Instrumental precision was based on duplicate analysis of sample digestates from each sample matrix, which resulted in RPDs $<2$ percent. Duplicate analysis of water samples for TSS ( $\mathrm{n}=3$ ) resulted in RPDs ranging from 1.5 to 25 percent, whereas triplicate analysis for TSS $(n=2)$ resulted in RSDs $<8$ percent. The duplicate analysis of drain sediments $(n=2)$ for PSA resulted in RPDs $<6$ percent for the fractions. Triplicate analyses of drain sediments $(\mathrm{n}=2)$ for PSA resulted in RSDs $<9$ percent for the fractions. The duplicate analysis of four drain sediments for TOC resulted in RPDs ranging from 14 to 32 percent. A replicate analysis of a TOC control material and one drain sediment resulted in RSDs of 6.7 and 25 percent.

Spikes: Recoveries of selenium [selenate $\left(\mathrm{Se}^{+6}\right)$, or selenomethionine] spiked into water samples $(n=8)$ ranged from 98 to 105 percent, averaging 103 percent. Recoveries of selenium spiked into sediment ( $\mathrm{n}=4)$, ranged from 100 to 102 percent, averaging 101 percent. Recoveries of selenium spikes added to water during analysis $(\mathrm{n}=5)$ ranged from 96 to 108 percent, averaging 105 percent. Analysis spikes of sediment $(n=3)$ ranged from 100 to 104 percent, averaging 102 percent.

Blank Equivalent Concentrations: Blank equivalent concentrations (BECs) were computed for selenium for each matrix and for TSS blanks analyzed with the drain water samples. Selenium BECs for water and sediment were $\leq$ their respective method detection limits (MDLs), whereas BECs for TSS were less than the TSS MDL. TSS sample data were corrected for procedural blanks, whereas total selenium sample data were not blank corrected.

Instrument Detection, Method Detection, and Method Quantitation Limits: The FIHGAAS instrument detection limit for selenium was $0.028 \mu \mathrm{g} / \mathrm{L}$, and $0.09 \mathrm{mg}$ for TSS. MDLs for each matrix for selenium were computed for each analytical block $(\mathrm{n}=3)$ using the formula:

$$
3\left(\mathrm{SD}_{\mathrm{b}}{ }^{2}+\mathrm{SD}_{\mathrm{s}}^{2}\right)^{1 / 2}
$$

where

$$
\begin{aligned}
\mathrm{SD}_{\mathrm{b}}= & \text { standard deviation of a blank }(\mathrm{n}=3) ; \text { and } \\
\mathrm{SD}_{\mathrm{s}}= & \text { standard deviation of a low level sample or } \\
& \text { spiked sample }(\mathrm{n}=3) .
\end{aligned}
$$

Calculated selenium MDLs for water were 0.16 to $0.13 \mu \mathrm{g} / \mathrm{L}$ and $0.009 \mu \mathrm{g} / \mathrm{g}$ dry weight for sediment. Method quantitation limits (MQLs) for each matrix were calculated as $3.3 \times$ MDLs. Selenium MQLs for water were 0.54 and $0.42 \mu \mathrm{g} / \mathrm{L}$ and 0.026 $\mu \mathrm{g} / \mathrm{L}$ for sediment. The MDL for TSS was $8.80 \mathrm{mg} / \mathrm{L}$ and the MQL was $29 \mathrm{mg} / \mathrm{L}$. Overall, quality-control results for the study were within acceptable limits as specified by USGS.

\section{References Cited}

American Public Health Association, 1998, Standard methods for the examination of water and wastewater (20th ed.), Method 2540: Washington, D.C., American Public Health Association, p. 257-258.

American Society for Testing and Materials, 2003, Standard test method for particle-size analysis of soils, D422-63 (2002), in Annual Book of ASTM Standards, v. 04.08. West Conshohocken, Pa., American Society for Testing and Materials, p. 10-17.

Universal Instruments Corporation, 1999, Operating manual for Model CM 5014 Coulometer. 
Tables 
Table 1. Total selenium concentrations in duplicates of unfiltered irrigation drain-water samples, Salton Sea, California, April 2009. [ID, identification; Rep, field replicate; $\mu \mathrm{g} / \mathrm{L}$, microgram per liter; SD, standard deviation; --, no data; <, less than; nc, not collected]

\begin{tabular}{|c|c|c|c|c|c|c|c|}
\hline \multirow[b]{2}{*}{ USGS ID } & \multirow[b]{2}{*}{ Field ID } & \multirow[b]{2}{*}{ Drain name/ID } & \multirow[b]{2}{*}{ Collection date } & \multicolumn{3}{|c|}{ Total selenium concentration } & \multirow[b]{2}{*}{ SD } \\
\hline & & & & $\begin{array}{l}\text { Rep } 1 \\
(\mu \mathrm{g} / \mathrm{L})\end{array}$ & $\begin{array}{l}\text { Rep } 2 \\
(\mu \mathrm{g} / \mathrm{L})\end{array}$ & $\begin{array}{l}\text { Mean } \\
(\mu \mathrm{g} / \mathrm{L})\end{array}$ & \\
\hline 46304 & Blank 2 & -- & $4 / 28 / 2009$ & $<0.16$ & -- & -- & -- \\
\hline 46238 & BLNDWATSE16A & -- & $4 / 17 / 2009$ & 1.68 & -- & -- & -- \\
\hline 46279,46280 & NLD1WATSE16 & Niland 1 & $4 / 25 / 2009$ & 5.15 & 5.09 & 5.12 & 0.04 \\
\hline 46281,46282 & NLD2WATSE16 & Niland 2 & $4 / 25 / 2009$ & 2.15 & 2.03 & 2.09 & 0.08 \\
\hline 46283,46284 & NLD3WATSE16 & Niland 3 & $4 / 25 / 2009$ & 1.89 & 1.77 & 1.83 & 0.09 \\
\hline 46285,46286 & NLD4WATSE16 & Niland 4 & $4 / 25 / 2009$ & 1.76 & 1.83 & 1.79 & 0.05 \\
\hline 46289,46290 & PUMCWATSE16 & Pumice & $4 / 23 / 2009$ & 4.14 & 4.10 & 4.12 & 0.03 \\
\hline 46232,46233 & QQQQWATSE16 & $\mathrm{Q}$ & $4 / 20 / 2009$ & 9.73 & 9.68 & 9.71 & 0.04 \\
\hline 46234,46235 & RRRRWATSE16 & $\mathrm{R}$ & $4 / 21 / 2009$ & 2.75 & 2.84 & 2.80 & 0.06 \\
\hline 46236,46237 & SSSSWATSE16 & $\mathrm{S}$ & $4 / 21 / 2009$ & 4.77 & 4.72 & 4.75 & 0.03 \\
\hline 46177,46178 & SFWHWATSE16 & San Felipe Wash & $4 / 16 / 2009$ & 2.66 & 2.70 & 2.68 & 0.03 \\
\hline 46293,46294 & TTTTWATSE16 & $\mathrm{T}$ & $4 / 21 / 2009$ & 1.98 & 1.90 & 1.94 & 0.06 \\
\hline 46155,46156 & TR01WATSE16 & Trifolium 1 & $4 / 18 / 2009$ & 5.61 & 4.75 & 5.18 & 0.60 \\
\hline 46291,46292 & TR12WATSE16 & Trifolium 12 & $4 / 23 / 2009$ & 7.22 & 7.32 & 7.27 & 0.07 \\
\hline 46157,46158 & TR13WATSE16 & Trifolium 13 & $4 / 19 / 2009$ & 2.61 & 2.57 & 2.59 & 0.03 \\
\hline 46167,46168 & TR22WATSE16 & Trifolium 22 & $4 / 16 / 2009$ & 4.79 & 5.01 & 4.90 & 0.15 \\
\hline 46169,46170 & TR23WATSE16 & Trifolium 23 & $4 / 16 / 2009$ & 3.71 & 3.63 & 3.67 & 0.05 \\
\hline 46173,46174 & TRSTWATSE16 & Trifolium Storm & $4 / 18 / 2009$ & 6.19 & 6.24 & 6.22 & 0.03 \\
\hline 46295,46296 & UUUUWATSE16 & $\mathrm{U}$ & $4 / 24 / 2009$ & 1.68 & 1.56 & 1.62 & 0.08 \\
\hline 46297, 46298 & VL05WATSE16 & Vail 5 & $4 / 23 / 2009$ & 1.91 & 1.96 & 1.93 & 0.04 \\
\hline 46299,46300 & WWWWWATSE16 & $\mathrm{W}$ & $4 / 24 / 2009$ & 4.01 & 4.18 & 4.10 & 0.12 \\
\hline 46301,46302 & ZSPLWATSE16 & Z Spill & $4 / 24 / 2009$ & 4.17 & 3.91 & 4.04 & 0.18 \\
\hline
\end{tabular}


Table 2. Total suspended solids concentrations in unfiltered Salton Sea, California, irrigation drain-water samples, April 2009.

[ID, identification; TSS, total suspended solids; $\mathrm{mg} / \mathrm{L}$, milligram per liter]

\begin{tabular}{|c|c|c|c|}
\hline \multirow{2}{*}{ Field ID } & \multirow{2}{*}{ Drain name/ID } & \multicolumn{2}{|c|}{ April, 2009} \\
\hline & & USGS ID & TSS (mg/L) \\
\hline BLNDWATSS16a & Blind A & 46154 & 45 \\
\hline BLNDWATSS16b & Blind B & 46213 & 72 \\
\hline LKLNWATSS16 & Lack \& Linsey Pond & 46153 & 25 \\
\hline NLD1WATSS16 & Niland 1 & 46252 & 196 \\
\hline NLD2WATSS16 & Niland 2 & 46253 & 28 \\
\hline NLD3WATSS16 & Niland 3 & 46254 & 154 \\
\hline NLD4WATSS16 & Niland 4 & 46255 & 62 \\
\hline OOOOWATSS16 & $\mathrm{O}$ & 46208 & 84 \\
\hline PPPPWATSS16 & $\mathrm{P}$ & 46152 & 95 \\
\hline POEDWATSS16 & Poe Rd & 46150 & 7.9 \\
\hline PUMCWATSS16 & Pumice & 46256 & 201 \\
\hline QQQQWATSS16 & Q & 46209 & 148 \\
\hline RRRRWATSS16 & $\mathrm{R}$ & 46210 & 106 \\
\hline SSSSWATSS16 & $\mathrm{S}$ & 46211 & 156 \\
\hline SFWHWATSS16 & San Felipe Wash & 46151 & 16 \\
\hline TTTTWATSS16 & $\mathrm{T}$ & 46212 & 160 \\
\hline TR01WATSS16 & Trifolium 1 & 46140 & 123 \\
\hline TR12WATSS16 & Trifolium 12 & 46257 & 116 \\
\hline TR13WATSS16 & Trifolium 13 & 46141 & 36 \\
\hline TR14WATSS16 & Trifolium 14 & 46142 & 44 \\
\hline TR18WATSS16 & Trifolium 18 & 46143 & 4.7 \\
\hline TR19WATSS16 & Trifolium 19 & 46144 & 12 \\
\hline FT20WATSS16 & Former Trifolium 20 & 46148 & 78 \\
\hline TR20WATSS16 & Trifolium 20 & 46145 & 67 \\
\hline TR22WATSS16 & Trifolium 22 & 46146 & 36 \\
\hline TR23WATSS16 & Trifolium 23 & 46147 & 53 \\
\hline TRSTWATSS16 & Trifolium Storm & 46149 & 41 \\
\hline UUUUWATSS16 & $\mathrm{U}$ & 46258 & 34 \\
\hline VL05WATSS16 & Vail 5 & 46259 & 36 \\
\hline WWWWWATSS16 & W & 46260 & 856 \\
\hline ZSPLWATSS16 & Z Spill & 46261 & 524 \\
\hline
\end{tabular}


Table 3. Selenium concentrations in sediment samples collected from Salton Sea, California, irrigation drains, April 2009.

[ID, identification; $\mu \mathrm{g} / \mathrm{g}$, micrograms per gram]

\begin{tabular}{|c|c|c|c|c|c|}
\hline USGS ID & Field ID & Matrix & Drain name/ID & $\begin{array}{l}\text { Moisture } \\
\text { (percent) }\end{array}$ & $\begin{array}{c}\text { Selenium } \\
\text { ( } \mu \mathrm{g} / \mathrm{g} \text { dry } \\
\text { weight) }\end{array}$ \\
\hline 46251 & BLNDSDTSE16 & $4 / 19 / 2009$ & Blind & 55.3 & 2.84 \\
\hline 46319 & BLNDSDTSE16B & $4 / 21 / 2009$ & Blind & 42.4 & 0.58 \\
\hline 46247 & LKLNSDTSE16 & $4 / 18 / 2009$ & Lack and Lindsay & 43.4 & 1.55 \\
\hline 46305 & NLD1SDTSE16 & $4 / 25 / 2009$ & Niland 1 & 54.7 & 1.15 \\
\hline 46306 & NLD2SDTSE16 & $4 / 25 / 2009$ & Niland 2 & 54.9 & 1.23 \\
\hline 46307 & NLD3SDTSE16 & $4 / 25 / 2009$ & Niland 3 & 55.0 & 0.71 \\
\hline 46308 & NLD4SDTSE16 & $4 / 25 / 2009$ & Niland 4 & 51.8 & 0.69 \\
\hline 46248 & OOOOSDTSE16 & $4 / 17 / 2009$ & $\mathrm{O}$ & 49.3 & 0.86 \\
\hline 46250 & PPPPSDTSE16 & $4 / 20 / 2009$ & $\mathrm{P}$ & 42.5 & 0.74 \\
\hline 46249 & POEDSDTSE16 & $4 / 19 / 2009$ & Poe & 25.4 & 0.25 \\
\hline 46309 & PUMCSDTSE16 & $4 / 23 / 2009$ & Pumice & 37.9 & 0.88 \\
\hline 46310 & QQQQSDTSE16 & $4 / 20 / 2009$ & Q & 54.3 & 2.58 \\
\hline 46311 & RRRRSDTSE16 & $4 / 21 / 2009$ & $\mathrm{R}$ & 38.7 & 0.55 \\
\hline 46312 & SSSSSDTSE16 & $4 / 21 / 2009$ & S & 47.2 & 0.99 \\
\hline 46179 & SFWHSDTSE16 & $4 / 16 / 2009$ & San Felipe Wash & 34.9 & 0.96 \\
\hline 46313 & TTTTSDTSE16 & $4 / 21 / 2009$ & $\mathrm{~T}$ & 40.2 & 0.63 \\
\hline 46240 & TR01SDTSE16 & $4 / 18 / 2009$ & Trifolium 1 & 67.9 & 3.10 \\
\hline 46314 & TR12SDTSE16 & $4 / 23 / 2009$ & Trifolium 12 & 28.4 & 0.29 \\
\hline 46241 & TR13SDTSE16 & $4 / 19 / 2009$ & Trifolium 13 & 43.8 & 1.28 \\
\hline 46242 & TR14SDTSE16 & $4 / 19 / 2009$ & Trifolium 14 & 55.1 & 2.64 \\
\hline 46243 & TR18SDTSE16 & $4 / 18 / 2009$ & Trifolium 18 & 44.4 & 5.00 \\
\hline 46244 & TR19SDTSE16 & $4 / 17 / 2009$ & Trifolium 19 & 57.0 & 2.20 \\
\hline 46180 & FT20SDTSE16 & $4 / 16 / 2009$ & Former Trifolium 20 & 22.1 & 0.08 \\
\hline 46245 & TR20SDTSE16 & $4 / 17 / 2009$ & Trifolium 20 & 50.6 & 0.91 \\
\hline 46181 & TR22SDTSE16 & $4 / 16 / 2009$ & Trifolium 22 & 39.8 & 0.64 \\
\hline 46182 & TR23SDTSE16 & $4 / 16 / 2009$ & Trifolium 23 & 42.4 & 0.69 \\
\hline 46246 & TRSTSDTSE16 & $4 / 18 / 2009$ & Trifolium Storm & 34.9 & 0.39 \\
\hline 46315 & UUUUSDTSE16 & $4 / 24 / 2009$ & $\mathrm{U}$ & 51.4 & 0.61 \\
\hline 46316 & VL05SDTSE16 & $4 / 23 / 2009$ & Vail 5 & 71.6 & 5.99 \\
\hline 46317 & WWWWSDTSE16 & $4 / 24 / 2009$ & W & 32.0 & 0.49 \\
\hline 46318 & ZSPLSDTSE16 & $4 / 24 / 2009$ & Z Spill & 32.0 & 0.51 \\
\hline
\end{tabular}


Table 4. Particle size distributions in sediment samples collected from Salton Sea, California, irrigation drains, April 2009.

[ID, identification; >, greater than; mm, millimeter]

\begin{tabular}{|c|c|c|c|c|c|c|}
\hline \multirow[b]{2}{*}{ USGS ID } & \multirow[b]{2}{*}{ Field ID } & \multirow[b]{2}{*}{$\begin{array}{c}\text { Drain } \\
\text { name/ID }\end{array}$} & \multicolumn{4}{|c|}{ Particle size category } \\
\hline & & & $\begin{array}{l}>2 \mathrm{~mm} \\
\text { (percent) }\end{array}$ & $\begin{array}{c}\text { Sand } \\
\text { (percent) }\end{array}$ & $\begin{array}{c}\text { Silt } \\
\text { (percent) }\end{array}$ & $\begin{array}{c}\text { Clay } \\
\text { (percent) }\end{array}$ \\
\hline 46277 & BLNDSDTOCa & Blind $\mathrm{A}$ & 0.5 & 18 & 53 & 29 \\
\hline 46278 & BLNDSDTOCb & Blind B & 0.5 & 19 & 35 & 45 \\
\hline 46224 & LKLNSDTOC16 & Lack \& Linsey Pond & 21 & 46 & 21 & 12 \\
\hline 46262 & NLD1SDTOC16 & Niland 1 & 0.2 & 3.6 & 46 & 50 \\
\hline 46263 & NLD2SDTOC16 & Niland 2 & 0.5 & 6.8 & 47 & 45 \\
\hline 46264 & NLD3SDTOC16 & Niland 3 & 0 & 0 & 32 & 68 \\
\hline 46265 & NLD4SDTOC16 & Niland 4 & 0.2 & 0 & 26 & 74 \\
\hline 46266 & OOOOSDTOC16 & $\mathrm{O}$ & 0.7 & 18 & 36 & 45 \\
\hline 46225 & PPPPSDTOC16 & $\mathrm{P}$ & 0.7 & 18 & 39 & 42 \\
\hline 46226 & POEDSDTOC16 & Poe Rd & 0.9 & 64 & 21 & 15 \\
\hline 46267 & PUMCSDTOC16 & Pumice & 0.5 & 25 & 54 & 20 \\
\hline 46268 & QQQQSDTOC16 & Q & 0.1 & 14 & 46 & 39 \\
\hline 46269 & RRRRSDTOC16 & $\mathrm{R}$ & 0.9 & 40 & 28 & 31 \\
\hline 46270 & SSSSSDTOC16 & S & 7.3 & 17 & 32 & 45 \\
\hline 46227 & SFWHSDTOC16 & San Felipe Wash & 0.4 & 48 & 35 & 16 \\
\hline 46272 & TTTTSDTOC16 & $\mathrm{T}$ & 0.2 & 21 & 35 & 44 \\
\hline 46214 & TR01SDTOC16 & Trifolium 1 & 1.1 & 15 & 35 & 49 \\
\hline 46271 & TR12SDTOC16 & Trifolium 12 & 0 & 59 & 22 & 19 \\
\hline 46215 & TR13SDTOC16 & Trifolium 13 & 0.7 & 39 & 40 & 20 \\
\hline 46216 & TR14SDTOC16 & Trifolium 14 & 0.4 & 4.3 & 59 & 36 \\
\hline 46217 & TR18SDTOC16 & Trifolium 18 & 1.4 & 71 & 18 & 9.6 \\
\hline 46218 & TR19SDTOC16 & Trifolium 19 & 0.5 & 25 & 59 & 15 \\
\hline 46222 & FT20SDTOC16 & Former Trifolium 20 & 0 & 88 & 7.5 & 4.7 \\
\hline 46219 & TR20SDTOC16 & Trifolium 20 & 0.2 & 16 & 33 & 50 \\
\hline 46220 & TR22SDTOC16 & Trifolium 22 & 1.0 & 52 & 21 & 26 \\
\hline 46221 & TR23SDTOC16 & Trifolium 23 & 11 & 42 & 23 & 23 \\
\hline 46223 & TRSTSDTOC16 & Trifolium Storm & 0 & 28 & 52 & 20 \\
\hline 46273 & UUUUSDTOC16 & $\mathrm{U}$ & 0.1 & 2.8 & 39 & 58 \\
\hline 46274 & VL05SDTOC16 & Vail 5 & 0.9 & 24 & 55 & 20 \\
\hline 46275 & WWWWSDTOC16 & $\mathrm{W}$ & 2.0 & 50 & 18 & 29 \\
\hline 46276 & ZSPLSDTOC16 & Z Spill & 11 & 53 & 17 & 20 \\
\hline
\end{tabular}


Table 5. Percent total organic carbon in sediment samples collected from Salton Sea, California, irrigation drains, April 2009.

[ID, identification]

\begin{tabular}{|c|c|c|c|}
\hline USGS ID & Field ID & $\begin{array}{c}\text { Drain } \\
\text { name/ID }\end{array}$ & $\begin{array}{c}\text { Total organic carbon } \\
\text { (percent) }\end{array}$ \\
\hline 46277 & BLNDSDTOCa & Blind $\mathrm{A}$ & 1.9 \\
\hline 46278 & BLNDSDTOCb & Blind B & 0.4 \\
\hline 46224 & LKLNSDTOC16 & Lack \& Linsey Pond & 3.7 \\
\hline 46262 & NLD1SDTOC16 & Niland 1 & 1.0 \\
\hline 46263 & NLD2SDTOC16 & Niland 2 & 1.1 \\
\hline 46264 & NLD3SDTOC16 & Niland 3 & 0.5 \\
\hline 46265 & NLD4SDTOC16 & Niland 4 & 0.5 \\
\hline 46266 & OOOOSDTOC16 & $\mathrm{O}$ & 1.1 \\
\hline 46225 & PPPPSDTOC16 & $\mathrm{P}$ & 0.7 \\
\hline 46226 & POEDSDTOC16 & Poe Rd & 0.3 \\
\hline 46267 & PUMCSDTOC16 & Pumice & 0.8 \\
\hline 46268 & QQQQSDTOC16 & $\mathrm{Q}$ & 1.1 \\
\hline 46269 & RRRRSDTOC16 & $\mathrm{R}$ & 0.8 \\
\hline 46270 & SSSSSDTOC16 & $\mathrm{S}$ & 1.2 \\
\hline 46227 & SFWHSDTOC16 & San Felipe Wash & 0.7 \\
\hline 46272 & TTTTSDTOC16 & $\mathrm{T}$ & 0.6 \\
\hline 46214 & TR01SDTOC16 & Trifolium 1 & 2.6 \\
\hline 46271 & TR12SDTOC16 & Trifolium 12 & 0.2 \\
\hline 46215 & TR13SDTOC16 & Trifolium 13 & 1.7 \\
\hline 46216 & TR14SDTOC16 & Trifolium 14 & 1.7 \\
\hline 46217 & TR18SDTOC16 & Trifolium 18 & 1.5 \\
\hline 46218 & TR19SDTOC16 & Trifolium 19 & 1.7 \\
\hline 46222 & FT20SDTOC16 & Former Trifolium 20 & 0.2 \\
\hline 46219 & TR20SDTOC16 & Trifolium 20 & 0.9 \\
\hline 46220 & TR22SDTOC16 & Trifolium 22 & 0.8 \\
\hline 46221 & TR23SDTOC16 & Trifolium 23 & 0.9 \\
\hline 46223 & TRSTSDTOC16 & Trifolium Storm & 0.2 \\
\hline 46273 & UUUUSDTOC16 & $\mathrm{U}$ & 0.8 \\
\hline 46274 & VL05SDTOC16 & Vail 5 & 2.9 \\
\hline 46275 & WWWWSDTOC16 & W & 0.9 \\
\hline 46276 & ZSPLSDTOC16 & Z Spill & 0.6 \\
\hline
\end{tabular}


Prepared by:

Rolla Publishing Service Center

For more information concerning this publication, contact:

Director

U.S. Geological Survey

Columbia Environmental Research Center

4200 New Haven Road

Columbia, M0 65201

(573) 875-5399

Or visit the Columbia Environmental Research Center website at: http://www.cerc.usgs.gov 


